\section{Effects of Light Intensity and Growth Rate on Tipburn Development and Leaf Calcium Concentration in Butterhead Lettuce}

\author{
Yuki Sago ${ }^{1}$ \\ Faculty of Agriculture, Yamaguchi University, Yamaguchi, 753-8515, Japan
}

Additional index words. artificial lighting, plant factory, soil-less cultivation, root calcium absorption, root water absorption

\begin{abstract}
Tipburn is a severe problem in producing butterhead lettuce under artificial lighting and develops as a consequence of decreased calcium concentrations in leaves. Here, we investigated the effects of light intensity on tipburn development and calcium concentration in leaves by comparing their growth rates. Butterhead lettuce was grown in a plant factory under artificial light at photosynthetic photon flux (PPF) densities of $150,200,250$, and $300 \mu \mathrm{mol} \cdot \mathrm{m}^{-2} \cdot \mathrm{s}^{-1}$. Fresh and dry weights of shoots, relative growth rate, the number of leaves, and the number of tipburned leaves significantly increased with light intensity. Associations existed between growth and tipburn occurrence. Calcium absorption rate per plant also increased with light intensity in association with increased water absorption rate. Consequently, calcium concentrations in the entire plant and outer leaves increased with light intensity. In contrast, calcium concentration in the inner enclosed leaves did not increase with light intensity. This pattern can be attributed to the higher mass flow of calcium to outer leaves than to inner leaves, driven by transpiration, under high light intensities. Thus, a lack of calcium in the inner leaves resulting from rapid growth may contribute to the frequent tipburn development.
\end{abstract}

Tipburn, a leaf marginal apex necrosis, is a serious problem in vegetable production under controlled environments (Cox et al., 1976), such as in closed plant production systems equipped with artificial light (Son and Takakura, 1989). Tipburn is generally considered a calcium-associated physiological disorder (Bangerth, 1979; Thibodeau and Minotti, 1969). The necrosis results from the rupturing of laticifer cells (Olson et al., 1967), and develops as a consequence of decreased calcium concentrations in the leaves (Barta and Tibbitts, 1991; Struckmeyer and Tibbitts, 1965). Many researchers have reported that tipburn is associated with rapid growth rate and high calcium demand in leaves (Collier and Tibbitts, 1982; Gaudreau et al., 1994; Saure, 1998). The rate of plant growth can be increased by controlling the cultivation environment, and light intensity is an important environmental factor in such stimulation. In a plant factory, which is a closed system equipped with artificial light and a controlled environment system to produce high-quality crops all year-round (Kozai, 2013; Kozai et al., 2016), plants are

Received for publication 25 Feb. 2016. Accepted for publication 21 June 2016 .

This study was supported by a Grant-in-Aid for Scientific Research (No. 26850157) and "Program to Disseminate Tenure Tracking System," MEXT, Japan.

I thank Shoko Fukuoka for technical assistance with the experiments.

${ }^{1}$ Corresponding author. E-mail: sago@yamaguchi-u. ac.jp. maximize the total efficiency of the production process. The stimulation of growth is important for optimizing production (Higashi et al., 2015; Murase et al., 2015). In particular, extension of the lightning period to continuous lightning has been used to produce crops at a higher rate under artificial light (Goto and Takakura, 1988; Oda et al., 1989). However, rapid plant growth under favorable environmental conditions leads to decreased calcium concentrations in leaves. In plant factories, butterhead lettuce (Lactuca sativa var. capitata L.) is considered as an important vegetable because it can be produced with high yield and has a high market value. However, the rapid growth leads to calcium deficiency and tipburn in the enclosed leaves. Therefore, the development of tipburn is frequent in butterhead lettuce production in plant factories (Lee et al., 2013; Son and Takakura, 1989) and can result in severe economic loss.

There are numerous reports of methods to prevent tipburn development, such as the use of tipburn-resistant varieties (Cox and McKee, 1976; Koyama et al., 2012), foliar spraying of calcium salts (Thibodeau and Minotti, 1969), supply of air to inner leaves (Goto and Takakura, 1992), reducing the length of the light period (Tibbitts and Rao, 1968), shortening the day/night cycle (Goto and Takakura, 2003), and altering the spectral characteristics of the light source (Kleemann, 2004). However, although many factors have been implicated in tipburn development, simultaneous measurement of the growth continuously cultivated at a very high rate to rate and calcium concentration in the leaves is rare.

The objectives of the present study was to determine the relationship between light intensity and tipburn development, in relation to plant growth rate and leaf calcium concentration to minimize tipburn while maintaining rapid growth in a plant factory. Butterhead lettuce was grown in a plant factory equipped with artificial light and was subjected to different light intensities to change plant growth rate. In addition, the rate of calcium absorption by roots and calcium concentration in leaves were determined to characterize the dependence of tipburn development on leaf calcium concentration and plant growth rates at varying light intensities.

\section{Materials and Methods}

Plant cultivation. All experiments were performed in a plant factory equipped with artificial lighting at the Faculty of Agriculture, Yamaguchi University, Japan. The room had two air conditioners (SZYA50CAV; Daikin Industries Ltd., Japan), a dehumidifier (MJ-180JX; Mitsubishi Electric Corp., Japan), a carbon dioxide supply system, and a deep flow soilless cultivation system. We controlled the air temperature, relative humidity, and carbon dioxide concentration in the cultivation area at $20{ }^{\circ} \mathrm{C}$, $60 \%$, and $1200 \mu \mathrm{mol} \cdot \mathrm{mol}^{-1}$, respectively. We cultivated butterhead lettuce (Lactuca sativa var. capitata L.) 'Pansoma' (Syngenta Japan K.K., Japan) for $35 \mathrm{~d}$ for all experiments. We sowed the seeds in polyurethane foam installed in plastic trays $(600 \times 300 \times 50 \mathrm{~mm})$ and supplied with nutrient solution. Two days after sowing, we illuminated the seedlings with continuous light using white fluorescent lamps (FHF32EX-N-H; Panasonic Corp., Japan). We set the $P P F$ density (PPFD) at the surface of the polyurethane foams to 200 $\mu \mathrm{mol} \cdot \mathrm{m}^{-2} \cdot \mathrm{s}^{-1}$. Ten days after sowing, we transplanted the seedlings into 48-hole floating panels $(900 \times 600 \times 50 \mathrm{~mm})$ and installed in a soilless cultivation system containing nutrient solution at a depth of $100 \mathrm{~mm}$. The cultivation system had two cultivation beds $(39,000 \times 600 \times 200 \mathrm{~mm})$, a solution tank (100 L), a pump (MD55-RM; Iwaki Co., Ltd., Japan), solution cooling unit (RKS-400FS; Orion Machinery Co., Ltd., Japan), solution heating unit (AWA1510; Hakko Electric Co., Ltd., Japan), and electrical conductivity (EC) and $\mathrm{pH}$ sensors (PCE-11M; Cem Co., Ltd., Japan). The pump circulated the nutrient solution continuously between the cultivation beds and the solution tank at $30 \mathrm{~L} \cdot \mathrm{min}^{-1}$. We controlled the $\mathrm{EC}, \mathrm{pH}$, and temperature of the nutrient solution with a computer at $2.0 \mathrm{dS} \cdot \mathrm{m}^{-1}, 6.2 \mathrm{pH}$, and $20^{\circ} \mathrm{C}$, respectively. Four fluorescent lamps were mounted above each bed, and the $P P F D$ at the surface of each panel was set at 150, 200, 250, and $300 \mu \mathrm{mol}$ $\mathrm{m}^{-2} \cdot \mathrm{s}^{-1}$ by adjusting the distances between the panels and lamps to $350,280,175$, and $150 \mathrm{~mm}$, respectively. To cultivate the plants at a high rate, plants were exposed to continuous light for all treatments. Twenty days 
after sowing, the seedlings were thinned to 24 plants per panel to increase the spacing between plants, and the plant density was then 44.4 plants $/ \mathrm{m}^{2}$. We used OAT House SA-prescription nutrient solution (OAT Agrio Co., Ltd., Japan) containing $17.1 \mathrm{~mm}$ $\mathrm{NO}_{3}{ }^{-}, 1.1 \mathrm{~mm} \mathrm{PO}_{4}{ }^{3-}, 1.6 \mathrm{~mm} \mathrm{SO}_{4}{ }^{2-}, 8.4 \mathrm{~mm}$ $\mathrm{K}^{+}, 1.5 \mathrm{mM} \mathrm{Mg}^{2+}$, and $3.9 \mathrm{mM} \mathrm{Ca}^{2+}$ for all experiments.

Measurement of samples. To determine the growth rate of the plants, we sampled 10 plants at 10,30 , and $35 \mathrm{~d}$ after sowing and harvested the shoots of each plant by cutting just below the cotyledonary node, and measured the fresh and dry weight of shoots. Furthermore, we counted the number of leaves and the number of tipburned leaves per plant. All leaves whose length was more than $5 \mathrm{~mm}$ were counted. To measure the dry weight, we dried each sample at $90{ }^{\circ} \mathrm{C}$ for $48 \mathrm{~h}$. We evaluated the relative growth rates to compare plant growth rate at different growth stages. To determine the plant growth rate from transplanting to harvesting, we calculated the relative growth rate between 10 and $35 \mathrm{~d}$ after sowing ( $\left.\mathrm{RGR}_{\mathrm{DAS} 35}\right)$. However, since growth rate may be affected by severe tipburn injury, we also determined the plant growth rate until tipburn injury began to develop (30 d after sowing), by calculating the relative growth rate between 10 and $30 \mathrm{~d}$ after sowing $\left(\mathrm{RGR}_{\mathrm{DAS} 30}\right)$. We calculated $\mathrm{RGR}_{\mathrm{DAS} 30}$ and $\mathrm{RGR}_{\mathrm{DAS} 35}$ for each plant using the following equations:

$$
\begin{aligned}
\mathrm{RGR}_{\mathrm{DAS} 30} & =\frac{\ln W_{\mathrm{DAS} 30}-\ln W_{\text {DAS } 10}}{20} \\
\mathrm{RGR}_{\mathrm{DAS} 35} & =\frac{\ln W_{\text {DAS35 }}-\ln W_{\text {DAS } 10}}{25}
\end{aligned}
$$

where $\ln W_{\text {DAS } 10}(\mathrm{~g}), \ln W_{\text {DAS30 }}(\mathrm{g})$, and $\ln$ $W_{\text {DAS35 }}(\mathrm{g})$ are natural logarithms of the dry weights of the shoot at 10,30 , and $35 \mathrm{~d}$ after sowing, respectively, and the numbers 20 and 25 (days) are the periods between sampling for $W_{\mathrm{DAS} 10}$ and $W_{\mathrm{DAS} 30}$ or $W_{\mathrm{DAS} 10}$ and $W_{\text {DAS35 }}$, respectively. To determine the relationships between the tipburn development and plant growth rate, a correlation analysis was performed between the number of tipburned leaves and fresh weight of shoots, the dry weight of shoots, the number of leaves, and the relative growth rate at 30 and $35 \mathrm{~d}$ after sowing.

To determine the calcium concentrations in the leaves, we analyzed the plants sampled at $35 \mathrm{~d}$ after sowing using standard procedures (Yasutake et al., 2009). We analyzed the 21 st and 31 st leaves from the cotyledons for the outer and inner leaves, respectively, based on previous research by Collier and Huntington (1983). The 31st leaf was enclosed within surrounding leaves, whereas the 21 st leaf was always exposed to environment. We dried each sample at $90{ }^{\circ} \mathrm{C}$ for $48 \mathrm{~h}$ and ashed them at $450^{\circ} \mathrm{C}$ for $8 \mathrm{~h}$ in an electric furnace (KBF794N1; Koyo Themo System Co., Ltd., Japan). We dissolved the ashed samples in dilute $\mathrm{HNO}_{3}$ to completely decompose the organic matter. Then, we measured the calcium ion concentrations in the dissolved ash solution with an ion chromatograph (ICA2000; TOA DKK Corp., Japan) following standard procedures.

Measurement of water and calcium absorption. We constructed a measuring device for the rates of water absorption $\left(\mathrm{mL} \cdot \mathrm{h}^{-1}\right)$ and calcium absorption $\left(\mu \mathrm{mol} \cdot \mathrm{h}^{-1}\right)$ per plant following the previous study (Sago et al., 2011a). This system consists of a root chamber $(70 \mathrm{~mm} \times 70 \mathrm{~mm} \times 70 \mathrm{~mm})$, a solution tank $(100 \mathrm{~mL})$, an electronic balance (FZ-300i; A\&D Co., Japan), a tubing pump (MP-1983E; As One Corp., Japan), and silicon tubes (4 $\mathrm{mm}$ in diameter). The pump circulates the nutrient solution continuously between the root chamber and the solution tank. The nutrient solution overflows the root chamber into the solution tank, and the volume of the nutrient solution in the root chamber is constant. We calculated the rate of water absorption per plant as the change in volume of nutrient solution within the solution tank over a given time interval. We also calculated the rate of calcium absorption per plant as the change in the concentration of calcium ions in the nutrient solution and the volume of nutrient solution within the solution tank and root chamber over a given time interval. The concentration of calcium ions was analyzed using ion chromatography (ICA-2000; DKK-TOA Co., Japan). We measured the rates of water and calcium absorption by the roots of butterhead lettuce plants at $35 \mathrm{~d}$ after sowing. For these measurements, we transferred the plants to the measuring device in a growth chamber (KCLP-1400ICT; Nippon Medical \& Chemical Instruments Co. Ltd., Japan), where we maintained the air temperature, humidity, and carbon dioxide concentration at $20^{\circ} \mathrm{C}$, $60 \%$, and $1200 \mu \mathrm{mol} \cdot \mathrm{mol}^{-1}$, respectively, under the artificial light of white fluorescent lamps (FHF16EX-N-H; Panasonic Co.) and PPFD of $150,200,250$, and 300 $\mu \mathrm{mol} \cdot \mathrm{m}^{-2} \cdot \mathrm{s}^{-1}$ at the uppermost leaf. We adjusted $\mathrm{EC}$ and $\mathrm{pH}$ of the nutrient solution to $2.0 \mathrm{dS} \cdot \mathrm{m}^{-1}$ and $6.2 \mathrm{pH}$, respectively. The rates of water and calcium absorption were measured for a period of $20 \mathrm{~min}$ and repeated at each light level three times with the same 10 plants.

Data analysis. Ten plants in each group were used for all measurements. Analysis of variance post hoc multiple comparison test (Tukey's honestly significant difference, $P<$ 0.05 ), and correlation and regression analysis were performed using the statistical software $\mathrm{R}$ version 3. 2. 5 (R Core Team, 2016, Austria).

\section{Results and Discussion}

Figure 1 shows the fresh and dry weights of shoots, $\mathrm{RGR}_{\mathrm{DAS} 30}$, number of leaves, and number of tipburned leaves of butterhead lettuce grown under different $P P F D$ at $30 \mathrm{~d}$ after sowing. The fresh and dry weights of shoots significantly and linearly increased with light intensity (Fig. 1A and B). Similarly, $\mathrm{RGR}_{\mathrm{DAS} 30}$ and the number of leaves significantly increased with light intensity (Fig. 1C and D). The dry weights of plants grown under 200,250 , and $300 \mu \mathrm{mol} \cdot \mathrm{m}^{-2} \cdot \mathrm{s}^{-1}$ $P P F D$ were $1.35-, 1.61-$, and 1.86 -fold higher, respectively, than those of plants grown under $150 \mu \mathrm{mol} \cdot \mathrm{m}^{-2} \cdot \mathrm{s}^{-1} P P F D$. The increases in fresh and dry weight, $\mathrm{RGR}_{\mathrm{DAS} 30}$, and the number of leaves can be attributed to the increased photosynthesis under the high light intensity. In general, the net photosynthetic rate in lettuce leaves increases linearly at relatively low PPFD (below 200 $\left.\mu \mathrm{mol} \cdot \mathrm{m}^{-2} \cdot \mathrm{s}^{-1}\right)$, and then increases asymptotically until saturated PPFD level $(\approx 500$ $\mu \mathrm{mol} \cdot \mathrm{m}^{-2} \cdot \mathrm{s}^{-1}$ ) (Tani et al., 2014). Thus, the growth rate of butterhead lettuce proportionally increased with light intensity under our experiment conditions. The number of tipburned leaves also increased with light
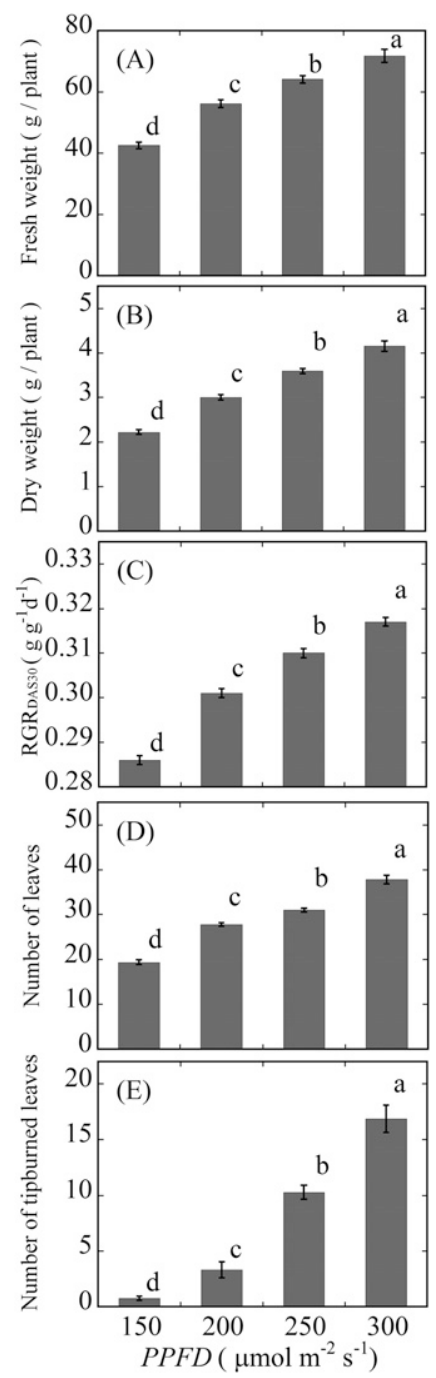

Fig. 1. (A) Fresh weight, (B) dry weight, (C) relative growth rate per day between 10 and $30 \mathrm{~d}$ after sowing ( RGR $_{\text {DAS30 }}$ ), (D) number of leaves, and (E) number of tipburned leaves of butterhead lettuce shoot grown under different photosynthetic photon flux densities (PPFDs) at $30 \mathrm{~d}$ after sowing. Means of 10 plants are shown with standard errors. Means with same letter are not significantly different by Tukey's honestly significant difference test at $P<0.01$. 
intensity (Fig. 1E). Tipburn injury appeared on the inner enclosed leaves. This finding is consistent with results reported by Barta and Tibbitts (1991) and Collier and Huntington (1983). The fresh weight did not reach $80 \mathrm{~g}$, which is the marketable weight of butterhead lettuce in Japan, under any treatment at $30 \mathrm{~d}$ after sowing. However, tipburn was observed under all treatments. These results suggest that tipburn frequently develops before the harvesting stage of butterhead lettuce grown under the standard light intensity (150-300 $\left.\mu \mathrm{mol} \cdot \mathrm{m}^{-2} \cdot \mathrm{s}^{-1}\right)$ for plant factory production.

Figure 2 shows the fresh and dry weights of shoots, $\mathrm{RGR}_{\mathrm{DAS} 35}$, number of leaves, and number of tipburned leaves of butterhead lettuce grown under different $P P F D$ at $35 \mathrm{~d}$ after sowing. Similarly to the values at $30 \mathrm{~d}$ after sowing, the fresh weight, dry weight,
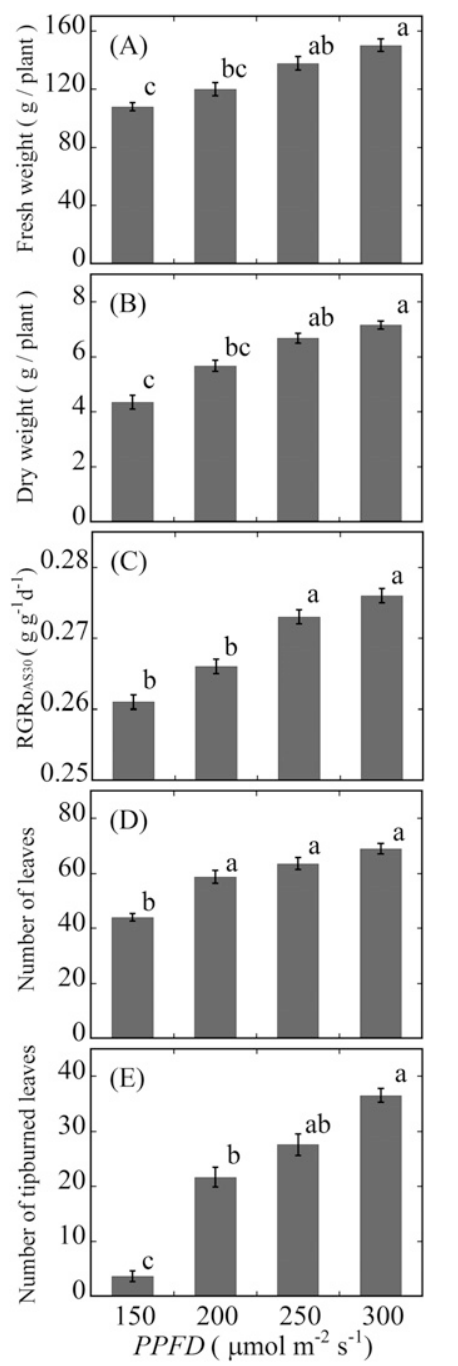

Fig. 2. (A) Fresh weight, (B) dry weight, (C) relative growth rate per day between 10 and $35 \mathrm{~d}$ after sowing (RGR DAS35 $_{3}$ ), (D) number of leaves, and (E) number of tipburned leaves of butterhead lettuce shoot grown under different photosynthetic photon flux densities (PPFDs) at $35 \mathrm{~d}$ after sowing. Means of 10 plants are shown with standard errors. Means with same letter are not significantly different by the Tukey's honestly significant difference test at $P<0.01$.
$\mathrm{RGR}_{\mathrm{DAS} 35}$, number of leaves, and number of tipburned leaves generally increased with increasing light intensity. The fresh weights reached marketable levels $(>80 \mathrm{~g})$ under all treatments at $35 \mathrm{~d}$ after sowing. The dry weights of plants grown under 200, 250, and $300 \mu \mathrm{mol} \cdot \mathrm{m}^{-2} \cdot \mathrm{s}^{-1} P P F D$ were $1.12-$, $1.32-$, and 1.42-fold higher, respectively, than those of plants grown under 150 $\mu \mathrm{mol} \cdot \mathrm{m}^{-2} \cdot \mathrm{s}^{-1}$. No significant differences between 250 and $300 \mu \mathrm{mol} \cdot \mathrm{m}^{-2} \cdot \mathrm{s}^{-1}$ were observed for any measurements. These results indicate that the increasing effect of high light intensity on plant growth at $35 \mathrm{~d}$ after sowing was relatively low. When tipburn develops, it appears as necrosis on the marginal apex of young leaves, and further growth is restricted. Thus, the deceleration of plant growth under high light intensity can be attributed to the development of severe tipburn before $35 \mathrm{~d}$ after sowing. The numbers of tipburned leaves developing under $300 \mu \mathrm{mol} \cdot \mathrm{m}^{-2} \cdot \mathrm{s}^{-1} \mathrm{PPFD}$ at 30 and $35 \mathrm{~d}$ after sowing were 22.5 - and 10.0-fold higher, respectively, than those of plants grown under $150 \mu \mathrm{mol} \cdot \mathrm{m}^{-2} \cdot \mathrm{s}^{-1}$.

Figure 3 shows the relationships between the number of tipburned leaves and the fresh weight, dry weight, $\mathrm{RGR}_{\mathrm{DAS} 30}$, and number of leaves of butterhead lettuce grown under different $P P F D$ conditions at $30 \mathrm{~d}$ after sowing. The number of tipburned leaves was significantly associated with fresh and dry weights, $\mathrm{RGR}_{\mathrm{DAS} 30}$, and number of leaves. Excellent linearity in the linear regressions was observed for these values, with a coefficient of correlation $(r)$ for each regression higher than 0.7 . These results suggest that differences in the development of tipburn under different light intensities are associated with plant growth rate. Similarly to the results at $30 \mathrm{~d}$ after sowing, at $35 \mathrm{~d}$ after sowing, the number of tipburned leaves was significantly associated with fresh weight, dry weight, $\mathrm{RGR}_{\mathrm{DAS} 35}$, and number of leaves of butterhead lettuce grown under different $P P F D$ conditions (Fig. 4). However, the $r$ value ( 0.48 to 0.64 ) for each regression was lower than that at $30 \mathrm{~d}$ after sowing. The growth rate decreases with the incidence of tipburn because further expansion of the leaves is restricted by tipburn development. Severe tipburn had already developed under high light intensity at $30 \mathrm{~d}$ after sowing. Thus, the lower $r$ for each regression at $35 \mathrm{~d}$ after sowing can be attributed to the nonuniformity in growth rate resulting from variation in the incidence of tipburn.
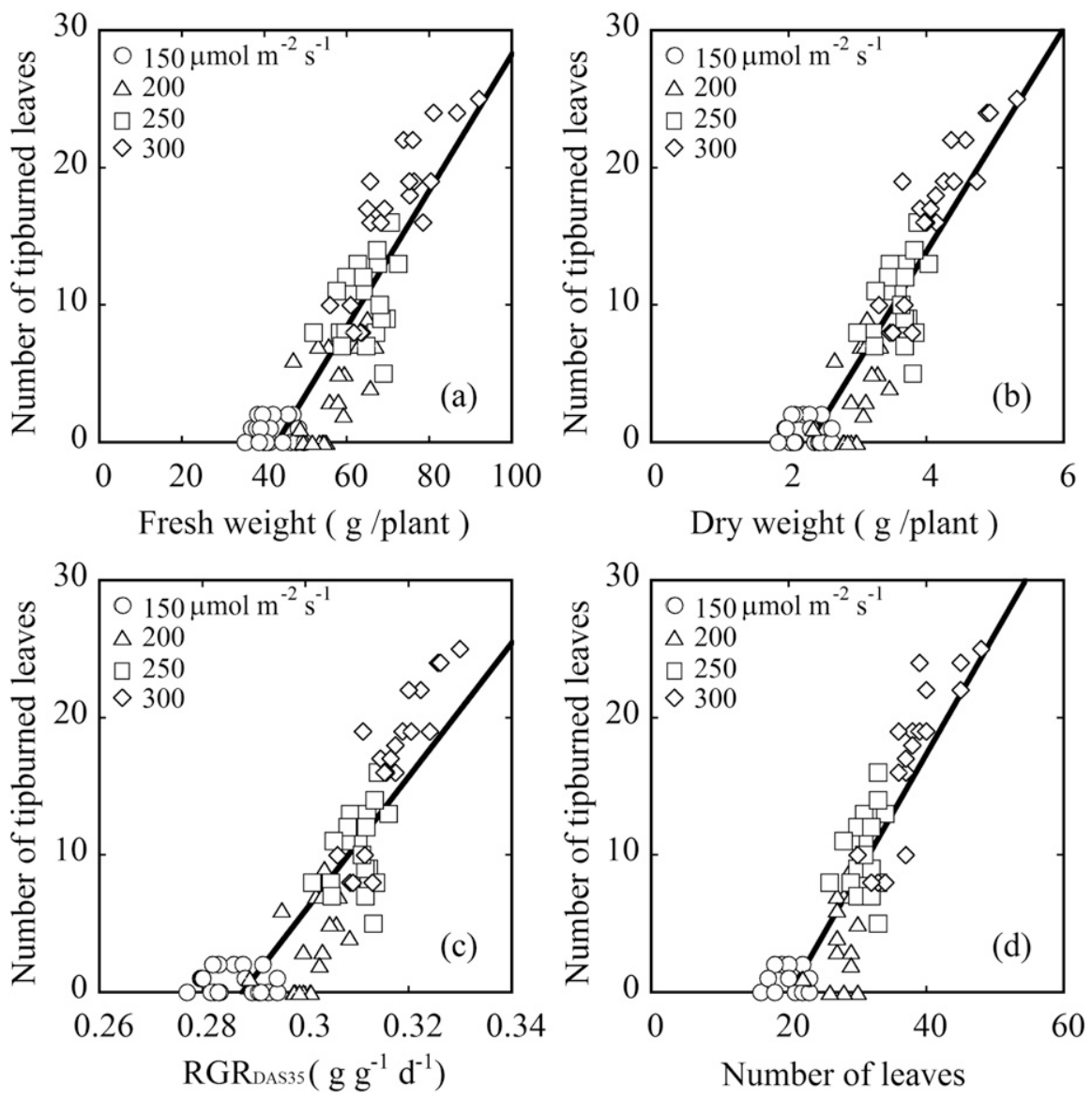

Fig. 3. Relationships between number of tipburned leaves at $30 \mathrm{~d}$ after sowing and the fresh weight, dry weight, relative growth rate for 10 to $30 \mathrm{~d}$ after sowing $\left(\operatorname{RGR}_{\mathrm{DAS} 30}\right)$, and the number of leaves in butterhead lettuce grown under different photosynthetic photon flux densities (PPFDs). The solid lines represent linear regressions fitted to each data set: (a) $y=-21.27+0.50 x ; r=0.869 ; P<0.01$; (b) $y=$ $-18.59+8.13 x ; r=0.902 ; P<0.01 ;$ (c) $y=-140.1+487.0 x ; r=0.0 .864 ; P<0.01 ;$ (d) $y=-17.66+$ $0.88 x ; r=0.882 ; P<0.01$. 
Figures 5 and 6 show the rates of water and calcium absorption per plant of butterhead lettuce roots under different $P P F D$ at $35 \mathrm{~d}$ after sowing. The rates of water and calcium absorption by roots increased with light intensity. This dependence of the rate of
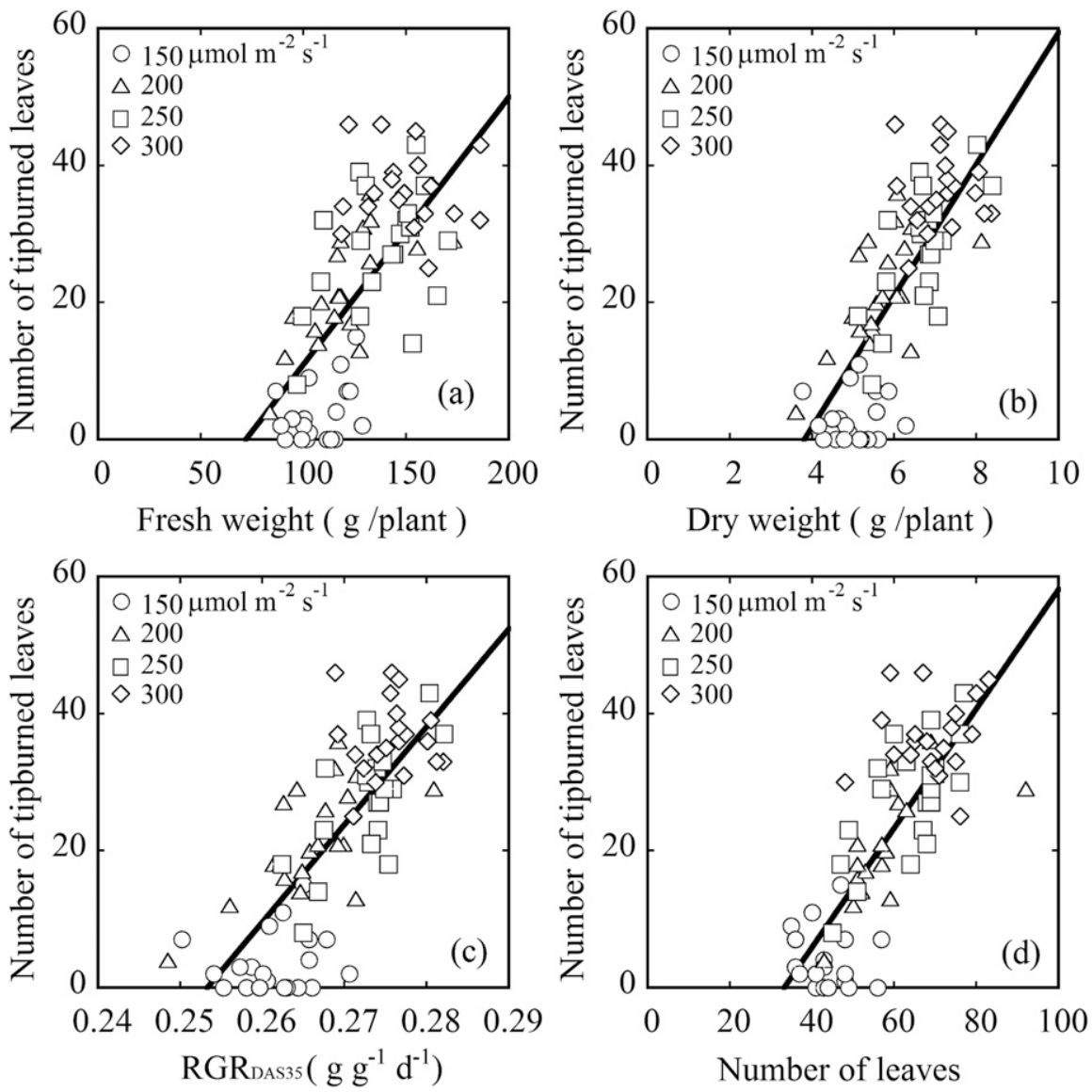

Fig. 4. Relationships between number of tipburned leaves at $35 \mathrm{~d}$ after sowing and the fresh weight, dry weight, relative growth rate for 10 to $35 \mathrm{~d}$ after sowing $\left(\mathrm{RGR}_{\mathrm{DAS} 35}\right)$, and number of leaves in butterhead lettuce grown under different photosynthetic photon flux densities (PPFDs). The solid lines represent linear regressions fitted to each data set: (a) $y=-27.893+0.39 x ; r=0.693 ; P<0.01$; (b) $y=$ $-36.45+9.59 x ; r=0.771 ; P<0.01 ;$ (c) $y=-361.2+1426.3 x ; r=0.773 ; P<0.01 ;$ (d) $y=-28.72+$ $0.87 x ; r=0.800 ; P<0.01$.

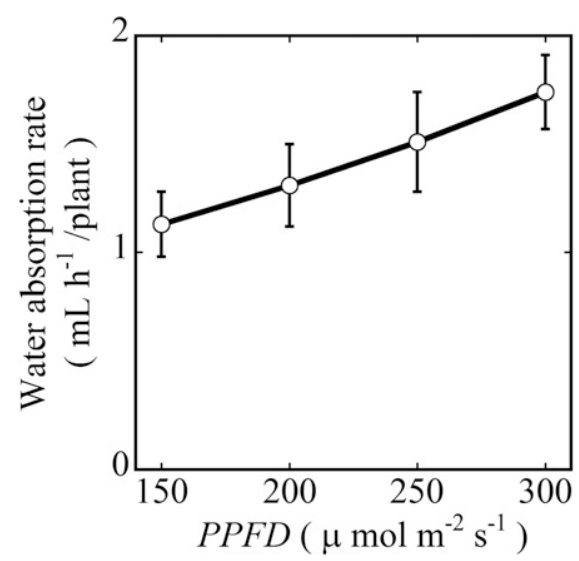

Fig. 5. Rates of water absorption of butterhead lettuce under different photosynthetic photon flux densities (PPFDs) at $35 \mathrm{~d}$ after sowing. Means of 10 plants are shown with standard errors.

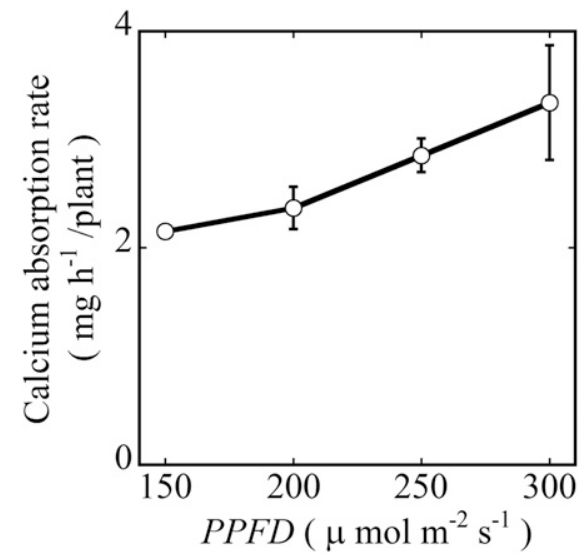
lettuce under different photosynthetic photon flux densities (PPFDs) at $35 \mathrm{~d}$ after sowing. Means of 10 plants are shown with standard errors.
Fig. 6. Rates of calcium absorption of butterhead the increase in water absorption by roots. The rates of calcium absorption under 200, 250, and $300 \mu \mathrm{mol} \cdot \mathrm{m}^{-2} \cdot \mathrm{s}^{-1}$ PPFD were 1.09-, 1.24-, and 1.31-fold higher, respectively, than those of plants grown under 150 $\mu \mathrm{mol} \cdot \mathrm{m}^{-2} \cdot \mathrm{s}^{-1}$ PPFD. This increasing effect of high light intensity on calcium absorption was lower than its effects on the dry weights of the shoot.

Calcium concentrations in the entire plant generally increased with light intensity (Fig. 7). Similarly, the calcium concentrations in the outer leaves generally increased with light intensity (Fig. 8). In contrast, calcium concentrations in the inner leaves were about the same among different light intensities. Calcium moves in xylem mainly in relation to the water flow arising from transpiration (Wiersum, 1966) and is not remobilized to the growing point once it is transported to actively transpiring leaves (Clarkson, 1984; Marschner, 1974). Furthermore, the inner leaf was enclosed within surrounding leaves, which decreased its transpiration potential. On the other hand, the outer leaves were always exposed to environment, and therefore could transpire freely. Thus, the lower calcium concentration in the inner leaves under high light intensities can be attributed to the higher mass flow of calcium driven by transpiration to the outer leaves than to the inner leaves.

From these results, it is evident that tipburn development is proportional to the fresh weight, dry weight, relative growth rate, and number of leaves. Calcium plays a major role in cell membrane function (HechtBuchholz, 1979) and in the cross-linking of cell wall structures (Taiz and Zeiger, 2010). The demand for calcium in leaves may increase with increasing growth rate in response to high light intensity, accompanied by expansion of the cell membrane and wall. However, calcium concentrations in the inner leaves do not increase with light intensity. Thus, differences in tipburn development among different light intensities can be

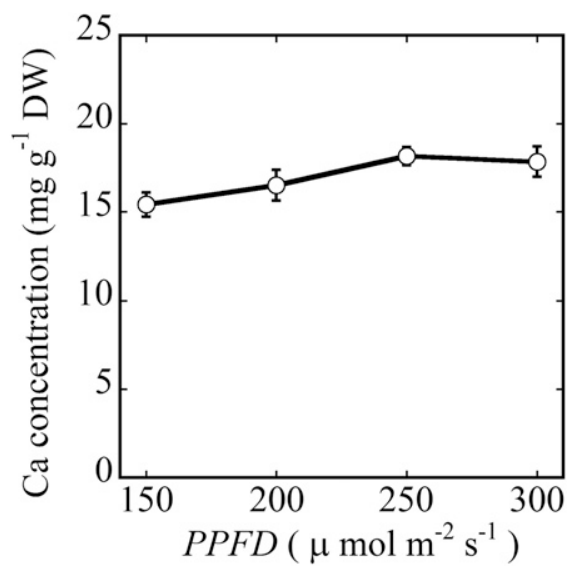

Fig. 7. Calcium concentrations in butterhead lettuce grown under different photosynthetic photon flux densities (PPFDs) at $35 \mathrm{~d}$ after sowing. Means of 10 plants are shown with standard errors. 


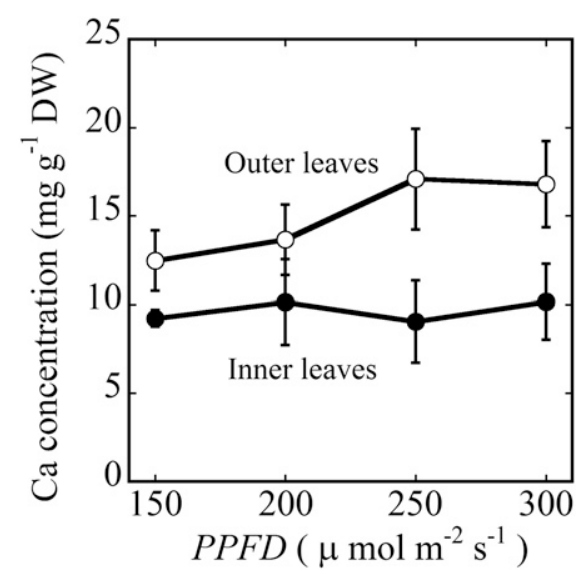

Fig. 8. Calcium concentrations in the inner leaf (31st leaf from the cotyledons; $)$ and the outer leaf (21st leaf from the cotyledons; $O$ ) in butterhead lettuce leaves grown under different photosynthetic photon flux densities (PPFDs) at $35 \mathrm{~d}$ after sowing. Means of 10 plants are shown with standard errors

attributed to differences in calcium demand associated with plant growth rate. These results suggest that the frequent development of tipburn under high light intensities in a plant factory may result from an imbalance between the demand and supply of calcium to the inner leaves. For the production of butterhead lettuce in plant factories, productivity increased with growth rate (Takatsuji, 2012). However, severe tipburn development was observed before the plant weight reached marketable weight at a high growth rate. Environmental factors, such as light intensity, air temperature, humidity, and air velocity, can be considered to affect root ion absorption via change in leaf transpiration and root water absorption (Sago et al., 2011b). Thus, to avoid tipburn while maintaining rapid growth in a plant factory, it is required to control environmental factors to increase calcium concentration in inner leaves while not impairing plant growth excessively.

\section{Literature Cited}

Bangerth, F. 1979. Calcium-related physiological disorders of plants. Annu. Rev. Phytopathol. 17:97-122.

Barta, D.J. and T.W. Tibbitts. 1991. Calcium localization in lettuce leaves with and without tipburn: Comparison of controlled-environment and field-grown plants. J. Amer. Soc. Hort. Sci. 116:870-875.
Clarkson, D.T. 1984. Calcium transport between tissues and its distribution in the plant. Plant Cell Environ. 7:449-456.

Collier, G.F. and V.C. Huntington. 1983. The relationship between leaf growth, calcium accumulation and distribution, and tipburn development in field-grown butterhead lettuce. Sci. Hort. 21:123-128.

Collier, G.F. and T.W. Tibbitts. 1982. Tipburn in lettuce. Hort. Rev. 4:49-65.

Cox, E.F. and J.M.T. McKee. 1976. A comparison of tipburn susceptibility in lettuce under field and green house conditions. J. Hort. Sci. 51:117-122.

Cox, E.F., J.M.T. McKee, and A.S. Dearman. 1976. The effect of growth rate on tipburn occurrence in lettuce. J. Hort. Sci. 51:297-309.

Gaudreau, L., J. Charbonneau, L.P. VeÂzina, and A. Gosselin. 1994. Photoperiodic and photosynthetic photon flux influence growth and quality of greenhouse-grown lettuce. HortScience. 29:1285-1289.

Goto, E. and T. Takakura. 1988. The effect of artificial light on the growth of lettuce. Acta Hort. 230:313-318.

Goto, E. and T. Takakura. 1992. Prevention of lettuce tipburn by supplying air to inner leaves. Trans. Amer. Soc. Agr. Eng. 35:641-645.

Goto, E. and T. Takakura. 2003. Reduction of lettuce tipburn by shortening day/night cycle. J. Agr. Meteorol. 59:219-225.

Hecht-Buchholz, C.L. 1979. Calcium deficiency and plant ultrastructure. Commun. Soil Sci. Plant Anal. 10:67-81.

Higashi, T., S. Nishikawa, N. Okamura, and H. Fukuda. 2015. Evaluation of growth under non$24 \mathrm{~h}$ period lighting conditions in Lactuca sativa L. Envrion. Control Biol. 53:7-12.

Kitano, M., T. Araki, S. Yoshida, and T. Eguchi. 1999. Dependence of calcium uptake on water absorption and respiration in roots of tomato plants (Lycopersicon esculentum). Biotronics 28:121-130.

Kleemann, M. 2004. Effect of photoselective plastic on the quality of lettuce. Acta Hort. 633:173-179.

Koyama, R., M. Sanada, H. Itoh, M. Kanechi, N. Inagaki, and Y. Uno. 2012. In vitro evaluation of tipburn resistance in lettuce (Lactuca sativa L). Plant Cell Tissue Organ Cult. 108:221-227.

Kozai, T. 2013. Resource use efficiency of closed plant production system with artificial light: Concept, estimation and application to plant factory. Proc. Jpn. Acad., Ser. B, Phys. Biol. Sci. 89:447-467.

Kozai, T., G. Niu, and M. Takagaki. 2016. Plant factory. Academic press, London, UK.

Lee, J.G., C.S. Choi, Y.A. Jang, S.W. Jang, S.G. Lee, and Y.C. Um. 2013. Effects of air temperature and air flow rate control on the tipburn occurrence of leaf lettuce in a closed-type plant factory system. Hort. Environ. Biotechnol. 54:303-310.
Marschner, H. 1974. Calcium nutrition of higher plants. Neth. J. Agr. Sci. 22:275-282.

Murase, H., B. Helm, and S. Oke. 2015. Investigation of a scanning laser projector as an energyefficient light source in plant production. Envrion. Control Biol. 53:71-76.

Oda, M., S. Aoki, M. Nagaoka, and K. Tsuji. 1989. Nutrient solution culture of leaf lettuce under artificial light II. Growth promotion induced by continuous illumination with low light intensity. Envrion. Control Biol. 27:75-82.

Olson, K.C., T.W. Tibbitts, and B.E. Struckmeyer. 1967. Morphology and significance of laticifer rupture in lettuce tipburn. Proc. Amer. Soc. Hort. Sci. 91:377-385.

Sago, Y., D. Yasutake, K. Hidaka, E. Yasunaga, T. Eguchi, S. Yoshida, and M. Kitano. 2011a. Kinetics of root ion absorption affected by environmental factors and transpiration I. Measurement system for intact roots. Envrion. Control Biol. 49:23-31.

Sago, Y., D. Yasutake, K. Hidaka, E. Yasunaga, T. Eguchi, S. Yoshida, and M. Kitano. 2011b. Kinetics of root ion absorption affected by environmental factors and transpiration III. A kinetic model integrated with transpiration. Envrion. Control Biol. 49:41-46.

Saure, M.C. 1998. Causes of the tipburn disorder in leaves of vegetables. Sci. Hort. 76:131-147.

Son, J.E. and T. Takakura. 1989. Effect of EC of nutrient solution and light condition on transpiration and tipburn injury of lettuce in a plant factory (in Japanese). J. Agr. Meteorol. 44:253-258.

Struckmeyer, B.E. and T.W. Tibbitts. 1965. Anatomy of lettuce leaves grown with a complete nutrient supply and without calcium or boron. Proc. Amer. Soc. Hort. Sci. 87:324-329.

Taiz, L. and E. Zeiger. 2010. Plant physiology. 5th ed. Sunderland, Sinauer Associates.

Takatsuji, M. 2012. The development to a plant factory-From engineering to agriculture-(in Japanese). Shokubutsu Kankyo Kogaku 24:163-166.

Tani, A., S. Shiina, K. Nakashima, and M. Hayashi. 2014. Improvement in lettuce growth by light diffusion under solar panels. J. Agr. Meteorol. 70:139-149.

Thibodeau, P.O. and P.L. Minotti. 1969. The influence of calcium on the development of lettuce tipburn. J. Amer. Soc. Hort. Sci. 94:372-376.

Tibbitts, T.W. and R.R. Rao. 1968. Light intensity and duration in the development of lettuce tipburn. Proc. Amer. Soc. Hort. Sci. 93:454 461.

Wiersum, L.K. 1966. Calcium content of fruits and storage tissues in relation to the mode of water supply. Acta Bot. Neerl. 15:406-418.

Yasutake, D., K. Hidaka, Y. Sago, T. Araki, M. Kitano, T. Kobayashi, and K. Ishikawa. 2009. Absorption and transport of water and ions in corn and sunflower plants grown under saline conditions. J. Agr. Meteorol. 65:19-26. 